\title{
US woos African states with science
}

\section{Washington}

Trade, it seems, no longer follows the flag but the lab. Washington's top science administrators departed for Africa last week for a ten-day trip aimed at stimulating scientific and technical cooperation with four "moderate" African states - Nigeria, Kenya, Senegal and Zimbabwe.

The sixteen-person delegation is headed by Dr Frank Press, director of the Office of Science and Technology Policy (OSTP). Other members include the administrator of the National Aeronautics and Space Administration, the acting director of the National Science Foundation and the director of the National Institutes of Health.

The practical goal of the delegation is to sign a number of agreements with the four countries for programmes of mutual cooperation. These range from setting up an experimental rural telecommunications system based on satellite technology in Senegal to a broad programme of vocational training courses for Nigerian science and engineering students in US universities and technical colleges.

The delegation's visit is also part of a broader strategy to strengthen links with four African countries with which the United States currently has the best relations. The intention is to help these countries to gain economic stability by promoting their technical efforts - and this in turn should provide a basis for their political stability.

In at least one case there are pragmatic reasons for the United States to want to maintain close political links. Nigeria is at present the nation's second largest supplier of petroleum (after Saudi Arabia); and continuation of this supply is important for the nation's security.

Some money is to be made available by the federal government so that agreements reached during the visit can be followed through, for example by arranging for the reciprocal visit of African scientists and policy makers to the United States. But for many countries, additional fiscal resources are less important than access to people and institutions in the United States able to help with their development problems.

OSTP expects agreements for cooperation to be signed in fields such as marine sciences, environmental resources, agriculture, remote sensing, satellite communications, alternative energy sources and the management of scientific research and technical information.

Three of the countries - Senegal, Kenya and Zimbabwe - will be able to benefit from financial and technical assistance offered under the term of US aid policies. In the fourth, Nigeria, the average income is above the limit for concessional terms to be permitted, and the United States will be looking for costs to be reimbursed.

Many of the agreements due to be signed cover areas that would have been the responsibility of the ill-fated Institute for Scientific and Technological Cooperation (ISTC). The setting up of ISTC was proposed by President Carter in 1978 and authorized by Congress last year, but because of a dispute with the Senate over funding is unlikely to come into existence. However, Dr Press said that the scope of the cooperative agreements, which will include feasibility studies of a Nigerianbased tuna industry and a project on ammonia-based synthetic fuels in Zimbabwe, will go beyond the role that had been intended for ISTC. The mission, according to Dr Press, has the full and active backing of President Carter, who had for example discussed it with Dr Robert Mugabe, Prime Minister of Zimbabwe, who

\section{Still looser UK guidelines}

The Genetic Manipulation Advisory Group (GMAG), responsible in the United Kingdom for the administration of guidelines on recombinant DNA research, has taken a substantial step towards oblivion. From now on, according to the latest revision of its guidelines applicable to university and industrial laboratories, experiments planned for the least stringent of the four categories of safeguards will not be scrutinized in advance by GMAG. Instead, the laboratory safety committee will have to carry through the standard GMAG hazard assessment and assure itself that proposed experiments do indeed belong in Category I. Laboratories will be required to inform GMAG in September each year of all experiments carried out under this licence in the previous year.

Sir William Henderson, chairman of GMAG, estimated last week that this step will relieve GMAG of 90 per cent of its present work. Because of rules which allow much other research to proceed once GMAG has been notified, it is estimated that only some two per cent of the experiments now being planned will have to await formal permission from GMAG.

The proposal that laboratories should be granted an annual licence to carry out experiments in Category I was first considered by GMAG in November 1978, at its first radical revision of the guidelines. The committee then considered that further information was necessary before the matter could be decided.

Sir William and other members of the committee are at pains to emphasize that this most recent revision of the GMAG procedures has been made possible by the accumulation of information in the past two years, and especially by evidence that the capacity of genetically manipulated visited Washington last month.

One disappointment for US - and possibly African - officials is that the delegation will not include $\mathrm{Dr}$ John Slaughter, a black who has been nominated by President Carter as director of the National Science Foundation.

After an inter-party dispute in the Senate over whether Republican members should assent to the appointment of Democrat nominees in the last few months before the Presidential election, Dr Slaughter's nomination was approved by a Senate committee last Wednesday, and is expected to move swiftly through the full Senate with little opposition. The delay has meant that Dr Slaughter will not be on the delegation and his place will be taken by Dr Donald Langenberg, the foundation's acting director.

David Dickson

bacterial cells to produce foreign protein molecules is limited. The assumption is that the production of foreign protein molecules from a single Escherichia coli bacterium with a foreign gene at a plasmid site chosen for expression will not exceed $10^{6}$. This, the argument goes, provides ways of quantifying the maximum amount of foreign protein produced in the infection of, say, the human gut by genetically altered bacteria. On this basis, the maximum amount of insulin produced in the gut by $E$. coli carrying an insulin gene could not exceed the equivalent of 0.6 units of the hormone, compared with the 20 or 30 units normally circulating in the body.

Laboratory safety committees will be expected to verify such estimates made by those wishing to carry out experiments, and to adjudicate specific proposals for categorization of the experiments concerned. GMAG itself expects that there will be further revisions of the guidelines, no doubt tantamount to further relaxations, in the not too distant future.

GMAG's own concerns are increasingly with proposals for large-scale manufacture - although the volume of applications so far has, apparently, been surprisingly small. Sir William considers, however, that both in respect of what GMAG requires from industrial applicants and more generally, British regulation of genetic manipulation is now less stringent than in the United States.

On large-scale production plants, for example, GMAG has taken the view that it is not feasible to enclose 100,000-litre fermentation vats in completely sealed containers or to operate them under negative pressure. Safety assessment, therefore, turns on an on-the-spot appraisal of the manufacturing plant and proposals for its 
operation.

Although it is too soon to know whether GMAG will or should go out of business, the recruitment of specialists in genetic manipulation to the committee may now become increasingly difficult. The group, in any case, will have its hands full with the scrutiny of proposals for work in categories II-IV of the guidelines procedures, and with the principles for regulating largescale manufacture. The reconstitution of the Dangerous Pathogens Advisory Group, expected soon, should, however, help to clarify GMAG's long-term future.

\section{Engineering research}

\section{Planning for more}

\section{Washington}

Federal policy-makers are now in the process of deciding whether the National Science Foundation (NSF) can provide an adequate framework for regenerating the health of the nation's engineering efforts. NSF officials are confident that it can. A prominent component of plans for reorganizing the foundation, formally presented last Thursday to the National Science Board responsible for foundation policy, is the creation of a new engineering directorate (see Nature 11 September). Applied science, which shares a directorate with engineering, would be distributed among the other research directorates.

Concern for the health of US engineering research has arisen as part of the wider debate about declining productivity and stagnating innovation. Equally important, however, has been what NSF acting director Dr Donald Langenberg describes as an "upsurge of interest" from engineering societies over the state of their profession and the role of federal support.

Both NSF and its critics agree that US engineering is in poor health. A rapidly escalating demand for engineers for largescale construction projects in the oil and chemical industries has created a national shortage of engineers. This situation will be exacerbated by the demands of new plants to be financed out of the government's $\$ 20,000$ synthetic fuels programme.

The shortage is reflected in the high salaries paid to engineering graduates, while another result is that few graduates are tempted to stay on at university to do research once they have completed their first degree. Many postgraduate courses are now largely filled with foreign students and NSF estimates that, overall, there are 2,000 empty positions in university engineering faculties.

Some universities are designing schemes to compensate. Carnegie-Mellon University in Pittsburgh, for example, plans to of fer loans of $\$ 1,000$ a month to PhD candidates, which need not be paid back if the candidate stays on and teaches.

However, there is general agreement that more than a piecemeal approach is needed; the question is the form it should take. Dr Leo Young, president of the Institute of Electrical and Electronic Engineers (IEEE), has proposed a "blue-ribbon commission" - somewhat similar to Britain's Finniston Committee - to look at the problems facing the profession.

In Congress, discussion has focused on a bill introduced by $\mathrm{Mr}$ George Brown, chairman of the House science and technology subcommittee, which proposes setting up a National Technology Foundation. Mr Brown admits that his proposal has been put forward chiefly as a vehicle for discussing a range of proposals and that a revised bill is likely to be represented to the next session of Congress.

However, many engineers have not lost the opportunity to vent their frustrations at what they consider to be a lack of support from the federal government in general and the NSF in particular - especially in fields outside space and defence research.

"Those university departments supported by the Department of Defense and the National Aeronautics and Space Administration have fared well, while civilian engineering, such as building technology and machinery design, have been neglected" complained Dr Bruno O. Weinschel, head of a private engineering company and secretary of IEEE.

National Science Board chairman Dr Lewis Branscomb of IBM admitted at congressional hearings on the bill that NSF support for engineering may have been weak in the past, but he insisted that this was now being remedied. He pointed out that for the past two years the board has proposed greater increases in the foundation's support for engineering research than for any other area of science.

NSF is hoping that its planned reorganization will go some way towards meeting its critics and will in particular head off any attempt to set up a new, separate institution (which might, in addition to the organization split, also be in a position to compete for funds). At a public meeting two weeks ago, held to discuss the reorganization proposals, $\mathrm{Dr}$ Langenberg said that engineering research could benefit financially from having its own directorate. He also hinted that reorganization plans were likely to be accompanied by a request for a significant increase in funds for engineering research when the foundation's budget request for 1982 goes to Congress in January.

Further financial commitments are likely to result from President Carter's decision about how to embrace science and engineering education in US schools and colleges, a report on which was sent to the White House by NSF and the Department of Education last month, and is expected to be made public shortly. But even if the Administration agrees that there is room for a larger role for engineering in the foundation, Congress may take some convincing. In debating the NSF appropriations in July, the House of Repre- sentatives rejected a proposal for a 10 per cent increase in funds for the engineering directorate.

The White House report is likely to have a good deal to say about engineering research in American universities and colleges. Although, elsewhere, engineering graduates tend to stay away from doctoral courses, in its United States the demand is still quite high. There is, however, increasing concern about the willingness of potential faculty members to teach.

Perhaps more significantly, the powerful House Appropriations Committee claimed that its restriction of the use of NSF funds planned for various innovation projects was imposed "to ensure that an unacceptable level of unbudgeted items does not erode funding for basic research programmes which is - and continues to be - the raison d'etre of the foundation".

These sentiments find an echo, though somewhat muted, within the scientific community. At the public meeting on 13 September, representatives of several of the NSF's advisory committees expressed concern that too great an emphasis on engineering and applied science could put a further squeeze on basic research. Dr Langenberg replied that he felt basic science was sufficiently robust not to be significantly threatened, but not everyone present was convinced. David Dickson

\section{Electronic publishing \\ Keyboard papers}

Those who wish to publish a research article in a journal, who are asked to referee a paper or who simply want to read what their colleagues have been publishing may in future have to turn to a computer terminal. The fully electronic scientific journal is still a few years off, however. But a group of British researchers is already beginning to consider its possibilities, in a project supported to the tune of $£ 256,000$ by the British Library.

The aim of the project, which begins in earnest in November, is to investigate whether electronic journals might ever be feasible, how much they would cost the user and the type of problems they would pose to users. The leg work is being done by groups at the University of Birmingham Loughborough University. The Birmingham group, under Professor P. Jarratt, will be providing the central computer facility and hardware and software to other participants in the project at a cost of $£ 122,000$. The Loughborough group, under Professor B. Shackel, will coordinate the setting up of an experimental electronic journal using the rest of the funds.

About 35-40 people dotted throughout universities in Britain will be collaborating. Each centre will provide its own terminal linked in to the Birmingham computer. The British Library funds will go towards 